\title{
JPEB
}

\section{KOMPENSASI SEBAGAI PENENTU KEPUASAN KERJA}

\author{
Mellasanti Ayuwardani ${ }^{1}$ dan Kusni Ingsih ${ }^{2 *}$ \\ ${ }^{1,2}$ Magister Manajemen, Fakultas Ekonomi dan Bisnis ,Universitas Dian Nuswantoro \\ Jalan Imam Bonjol Semarang 50131, Indonesia \\ *Corresponding Author: kusningsih@dosen.dinus.ac.id
}

Diterima: Oktober 2015; Direvisi: Januari 2016; Dipublikasikan: Maret 2016

\begin{abstract}
Although the economic situation in Indonesia slowed in 2015, the retail industry is expected to continue to grow until 2017. PT Matahari Department Store Tbk ("Matahari" or the "Company") is one of the leading retail company in Indonesia.. Each executive was well aware of the importance of customer satisfaction faithful. However, not all executives understand the importance of creating customer satisfaction and loyalty in the employee rate. Job satisfaction is also linked to the performance of the organization. Cases are mainly in the service industry, where workers are not satisfied many customers often lead to dissatisfaction. The managers can potentially increase the motivation of employees through efforts to increase job satisfaction. The analytical method used is explanatory research method. The sample selection using purposive sampling. The samples used were 86 employees Matahari Department Store Paragon Semarang branch. Methods of data analysis in this study uses Multiple Linear Regression Analysis. Studies show that there are three ways to improve the job satisfaction of employees: first, that the compensation is the strongest factors that directly affect their job satisfaction, second, work environment factors that will either be able to create their motivation that will impact on work satisfaction, and third, a factor that can increase job satisfaction is clearly the work design will be able to create their work motivation, which in turn will have an impact on their job satisfaction.
\end{abstract}

Keywords: Compensation; Work Design; Work Environment; Motivation; Job Satisfactioan

\section{ABSTRAK}

Meskipun keadaan ekonomi di Indonesia melambat di tahun 2015, industri ritel masih diprediksi akan terus berkembang hingga tahun 2017. PT Matahari Department Store Tbk (Matahari atau Perseroan) adalah salah satu perusahaan ritel terkemuka di Indonesia. Setiap eksekutif sadar betul akan pentingnya kepuasan pelanggan setia. Namun, tidak semua eksekutif memahami pentingnya menciptakan kepuasan dan loyalitas di tingkat karyawan. Kepuasan kerja juga memiliki kaitan dengan kinerja organisasi. Kasus yang terutama terjadi di industri jasa, di mana para pekerja yang tidak puas kerap memicu ketidakpuasan banyak pelanggan. Para manajer dapat secara potensial meningkatkan motivasi para karyawan melalui berbagai usaha untuk meningkatkan kepuasan kerja.. Metode analisis yang digunakan adalah metode explanatory research. Pemilihan sampel menggunakan puposive sampling. Sampel yang digunakan adalah 86 orang karyawan Matahari Departement Store cabang Paragon kota Semarang. Metode analisis data dalam penelitian ini menggunakan Analisis Regresi Linear Berganda. Studi menunjukkan bahwa ada tiga cara untuk meningkatkan kepuasan kerja para karyawan: pertama, bahwa kompensasi merupakan faktor terkuat yang secara langsung berpengaruh terhadap kepuasan kerja mereka, kedua, faktor lingkungan kerja yang baik akan mampu menciptakan motivasi mereka yang akan berdampak pada kepuasan kerjanya, dan ketiga, faktor yang dapat meningkatkan kepuasan kerja adalah desain kerja yang jelas akan mampu menciptakan motivasi kerja mereka, yang pada akhirnya akan berdampak pada kepuasan kerja mereka.

Kata Kunci: Kompensasi; Desain Kerja; Lingkungan Kerja; Motivasi Kerja; Kepuasan Kerja 


\section{PENDAHULUAN}

Melambatnya ekonomi di Indonesia tahun 2015 menyebabkan industri ritel pun terkena imbasnya. Perkembangan industri ini terpantau melambat yang di sebabkan oleh turunnya daya beli masyarakat, indeks kepercayaan konsumen (IKK) serta lemahnya nilai tukar rupiah terhadap dollar Amerika Serikat. Meskipun keadaan ekonomi di Indonesia melambat di tahun 2015, industri ritel masih diprediksi akan terus berkembang hingga tahun 2017. PT Matahari Department Store Tbk ("Matahari" atau "Perseroan") adalah salah satu perusahaan ritel terkemuka di Indonesia yang menyediakan perlengkapan pakaian, aksesoris, produk-produk kecantikan dan rumah tangga dengan harga terjangkau. Matahari bermitra dengan pemasok pemasok terpercaya di Indonesia dan luar negeri untuk menyediakan kombinasi barang-barang fashion berkualitas tinggi yang dapat diterima oleh konsumen yang sadar akan nilai suatu produk (Info Matahari, 2016).

Perusahaaan-perusahaan terus menyelidiki prioritas bisnisnya dan menemukan berbagai cara memberikan nilai lebih kepada pelanggan, pemegang saham, karyawan, dan masyarakat di mana mereka berada. Setiap eksekutif sadar betul akan pentingnya kepuasan pelanggan setia. Namun, tidak semua eksekutif memahami pentingnya menciptakan kepuasan dan loyalitas di tingkat karyawan. Kepuasan kerja juga memiliki kaitan dengan kinerja organisasi. Kasus yang terutama terjadi di industri jasa, di mana para pekerja yang tidak puas kerap memicu ketidakpuasan banyak pelanggan.(Noe, dkk, 2011).

Vecchio (Wibowo, 2013) menyatakan kepuasan kerja sebagai pemikiran, perasaan dan kecenderungan tindakan seseorang yang merupakan sikap seseorang terhadap pekerjaan. Para manajer dapat secara potensial meningkatkan motivasi para karyawan melalui berbagai usaha untuk meningkatkan kepuasan kerja (Kreitner dan Angelo, 2005). Berdasarkan pra survey yang dilakukan pada 30 orang karyawan Matahari Departement Store Kantor Cabang Paragon Semarang ditemukan bahwa masih terdapat $50 \%$ karyawan yang belum puas terhadap bayaran yang diterima dan kesempatan promosi. Berdasarkan kondisi ini, maka peneliti tertarik untuk meneliti dengan topik ini.

\section{TINJAUAN PUSTAKA}

Setiap organisasi membutuhkan motivasi para karyawannya. Motivasi (motivation) adalah proses-proses psikologi yang menjelaskan intensitas, arahan dan ketekunan seorang individu untuk mencapai tujuannya atau goal-directed behavior (Kreitner dan Angelo, 2005). Sedangkan Stephen P. Robbins (Wibowo, 2013) menyatakan motivasi sebagai proses yang menyebabkan intensitas (intensity), arah (direction) dan usaha terus-menerus (persistence) individu menuju pencapaian tujuan. Intensitas menunjukkan seberapa keras seseorang berusaha. Tetapi intensitas tinggi tidak mungkin mengarah pada hasil kinerja yang baik, kecuali usaha dilakukan dalam arah yang menguntungkan organisasi. Tujuan motivasi menurut Satrianegara dan Siti (2009) adalah untuk mengubah perilaku bawahan sesuai dengan keinginan pimpinan, meningkatkan kegairahan kerja, meningkatkan disiplin, meningkatkan kesejahteraan, meningkatkan moral dan loyalitas, meningkatkan rasa tanggung jawab karyawan pada tugas-tugasnya, serta meningkatkan produktivitas dan efisiensi. Tujuan organisasi dicapai salah satunya melalui pembuatan desain pekerjaan masing-masing bidang kerja. Desain pekerjaan (job design) adalah aplikasi dari teori motivasi pada struktur kerja untuk memperbaiki produktivitas dan kepuasan (Daft, 2003). Pendekatan pada desain pekerjaan umumnya diklasifikasikan sebagai penyederhanaan pekerjaan, perputaran pekerjaan, perluasan pekerjaan dan pengayaan pekerjaan. Desain pekerjaan (job design) merupakan proses penentuan tugas yang akan dilaksanakan, metode yang digunakan untuk melaksanakan tugas, dan bagaimana pekerjaan berhubungan dengan pekerjaan lainnya di dalam organisasi (Simamora, 2004). Faktor lain yang tidak kalah penting dalam mencapai 
tujuan adalah lingkungan kerja. Lingkungan kerja merupakan suatu hal yang penting dalam suatu organisasi (Paramita, Wendi dan Agung, 2013). Lingkungan kerja yang baik, tentunya merupakan harapan bagi setiap karyawan karena dengan lingkungan kerja yang baik tentunya para karyawan akan dapat melaksanakan tugas-tugasnya dengan baik pula. Dengan lingkungan kerja yang baik, maka secara otomatis dapat memberikan kepuasan tersendiri bagi karyawan. Jenis lingkungan kerja terbagi menjadi 2 yakni: (a) lingkungan kerja fisik, dan (b) lingkungan kerja non fisik". Lingkungan yang sehat memungkinkan manusia bekerja secara sehat dan bergairah (Danim, 2008). Hasil dari pelaksanaan tugas yang baik berujung pada kompensasi yang mereka harapkan.

Daft (2010) berpendapat bahwa kompensasi adalah total seluruh imbalan yang diterima para karyawan sebagai pengganti jasa yang telah mereka berikan. Kompensasi adalah total seluruh imbalan yang diterima para karyawan sebagai pengganti jasa yang telah mereka berikan. Tujuan umum pemberian kompensasi adalah untuk menarik, mempertahankan dan memotivasi karyawan. Besarnya kompensasi mencerminkan status, pengakuan dan tingkat pemenuhan kebutuhan yang dinikmati oleh karyawan bersama keluarganya. Jika balas jasa yang diterima karyawan semakin besar berarti jabatannya semakin tinggi, statusnya semakin baik dan pemenuhan kebutuhan yang dinikmatinya semakin banyak pula. Dengan demikian, kepuasan kerjanya juga semakin baik. Kepuasan kerja adalah keadaan emosional yang menyenangkan atau tidak menyenangkan di mana para karyawan memandang pekerjaan mereka (Handoko, 2012). Para karyawan dapat juga memperoleh kepuasan dari pekerjaan mereka melalui beberapa faktor nonfinansial.

\section{Hubungan Kompensasi dan Motivasi}

Istilah kompensasi (compensation) adalah semua pembayaran yang berupa uang, dan semua barang atau komoditas yang digunakan sebagai pengganti uang untuk memberi penghargaan pada pegawai (Daft, 2010). Kompensasi adalah total seluruh imbalan yang diterima para karyawan sebagai pengganti jasa yang telah mereka berikan. Tujuan umum pemberian kompensasi adalah untuk menarik, mempertahankan dan memotivasi karyawan. Besarnya kompensasi mencerminkan status, pengakuan dan tingkat pemenuhan kebutuhan yang dinikmati oleh karyawan bersama keluarganya. Jika balas jasa yang diterima karyawan semakin besar berarti jabatannya semakin tinggi, statusnya semakin baik dan pemenuhan kebutuhan yang dinikmatinya semakin banyak pula. Teori tersebut sesuai dengan penelitian Agus Dwi Nugroho dan Kunartinah (2012) yang menyatakan kompensasi berpengaruh positif dan signifikan terhadap motivasi kerja. Berdasarkan uraian di atas, dapat disusun hipotesis 1 sebagai berikut:

H1: Ada pengaruh positif kompensasi terhadap motivasi kerja

\section{Hubungan Desain Pekerjaan dan Motivasi}

Desain pekerjaan (job design) merupakan proses penentuan tugas yang akan dilaksanakan, metode yang digunakan untuk melaksanakan tugas, dan bagaimana pekerjaan berhubungan dengan pekerjaan lainnya di dalam organisasi (Henry, 2004). Satu pekerjaan yang membosankan dan monoton menghalangi motivasi untuk berprestasi baik, sedangkan suatu pekerjaan yang menantang akan meningkatkan motivasi (Kreitner dan Angelo, 2005). Motivasi (motivation) adalah proses-proses psikologi yang menjelaskan intensitas, arahan dan ketekunan seorang individu untuk mencapai tujuannya atau goal-directed behavior menurut Robert Kreitner dan Angelo (2005). Teori tersebut sesuai dengan penelitian Arief Subyantoro (2009) yang menyatakan desain pekerjaan berpengaruh langsung dan signifikan terhadap motivasi kerja. Di sisi lain, motivasi yang jelas berkaitan dengan tujuan organisasi karena mereka tertarik dalam meningkatkan prestasi kerja, meningkatkan kualitas, dan mengurangi absensi mahal melalui desain ulang pekerjaan. Namun, meningkatkan aspek motivasi 
pekerjaan ini dapat menghasilkan lebih banyak kesalahan, dan lebih stres. Di samping itu, menyederhanakan pekerjaan untuk meningkatkan efisiensi mungkin membuatnya kurang bermakna bagi karyawan, karena pekerjaan desain ulang mungkin memiliki konsekuensi yang tidak diinginkan, semua pendekatan desain pekerjaan harus dipertimbangkan. Mengetahui semua pendekatan dan hasil mereka dapat membantu pengusaha membuat keputusan desain pekerjaan yang lebih cerdas (Paul, M.A. \& Thayer, W., 2001). Berdasarkan uraian di atas, dapat disusun hipotesis 2 sebagai berikut:

$\mathrm{H} 2$ : Ada pengaruh positif desain kerja terhadap motivasi kerja

\section{Hubungan Lingkungan Kerja dan Motivasi}

Alex S. Niti Semito dalam Widya, Wendi dan Agung (2013) berpendapat, lingkungan kerja adalah segala sesuatu yang ada disekitar para pekerja dan yang dapat mempengaruhi dirinya dalam menjalankan tugas-tugas yang dibebankan kepadanya. Motivasi menurut M. Fais dan Sitti (2009) diartikan sebagai pernyataan perasaan atau pikiran yang membantu terciptanya kerja yang optimal. Teori tersebut sesuai dengan penelitian Astri Aslam, Asri Laksmi dan Gunawan Pamudji W. (2013) yang menyatakan lingkungan kerja berpengaruh signifikan dan positif terhadap motivasi kerja. Berdasarkan uraian di atas, dapat ditarik hipotesis 3 sebagai berikut:

H3: Ada pengaruh positif lingkungan kerja terhadap motivasi kerja

\section{Hubungan Kompenasasi dan Kepuasan Kerja}

William B. Werther dan Keith Davis (Hasibuan, 2005) menyatakan bahwa kompensasi adalah apa yang seorang pekerja terima sebagai balasan dari pekerjaan yang diberikannya. Tujuan pemberian kompensasi (balas jasa) antara lain adalah sebagai ikatan kerja sama, kepuasan kerja, pengadaan efektif, motivasi, stabilitas karyawan, disiplin serta pengaruh serikat buruh dan pemerintah (Hasibuan, 2005). Kepuasan kerja adalah sikap umum terhadap pekerjaan seseorang, yang menunjukkan perbedaan antara jumlah penghargaan yang diterima pekerja dan jumlah yang mereka yakini seharusnya mereka terima menurut Robbins (Wibowo, 2013). Sedangkan Vecchio (Wibowo, 2013) menyatakan bahwa kepuasan kerja sebagai pemikiran, perasaan dan kecenderungan tindakan seseorang yang merupakan sikap seseorang terhadap pekerjaan. Teori tersebut sesuai dengan penelitian Agus Dwi Nugroho dan Kunartinah (2012) yang menyatakan bahwa kompensasi berpengaruh positif dan signifikan terhadap kepuasan kerja. Berdasarkan uraian di atas, dapat ditarik hipotesis 4 sebagai berikut: H4 : Ada pengaruh positif kompensasi terhadap kepuasan kerja

\section{Hubungan Desain Pekerjaan dan Kepuasan Kerja}

Desain kerja menurut Wibowo (2013) diartikan mengubah konten dan/atau proses pekerjaan spesifik untuk meningkatkan kepuasan kerja dan kinerja. Reaksi karyawan yang simpatik terhadap desain pekerjaan berdampak pada penyelesaian pekerjaan yang lebih cepat, kepuasan kerja yang lebih tinggi, ketidakhadiran yang lebih sedikit, keluhan yang lebih jarang dan putaran karyawan yang lebih rendah (Henry, 2004). Spesialisasi yang sempit dan kaku menjauhkan akan karyawan dari seluruh produk atau jasa. Hal ini menciptakan potensi keterasingan, mengurangi kepuasan kerja, dan membatasi tanggung jawab untuk kualitas. Spesialisasi juga dapat membatasi potensi interaksi dengan dan dukungan dari rekan-rekan, dan mengurangi kemampuan individu/karyawan untuk menyelesaikan masalah (Totterdill, $\mathrm{P}$, 2017). Greenberg dan Baron (Wibowo, 2013) mendeskripsikan kepuasan kerja sebagai sikap positif atau negatif yang dilakukan individual terhadap pekerjaan mereka. Teori tersebut sesuai dengan penelitian Oktina Hafanti (2015) yang menyatakan bahwa desain tugas berpengaruh langsung terhadap kepuasan kerja karyawan. Berdasarkan uraian di atas, dapat ditarik hipotesis 5 sebagai berikut:

H5: Ada pengaruh positif desain kerja terhadap kepuasan kerja 


\section{Hubungan Lingkungan Kerja dan Kepuasan Kerja}

Rivai dalam Widya, Wendi dan Agung (2013) mendefinisikan lingkungan kerja adalah keseluruhan sarana dan prasarana yang ada disekitar karyawan yang sedang melakukan pekerjaan itu sendiri. Dengan lingkungan kerja yang baik, maka secara otomatis dapat memberikan kepuasan tersendiri bagi karyawan (Widya, Wendi dan Agung, 2013). Kepuasan kerja adalah keadaan emosional yang menyenangkan atau tidak menyenangkan dengan mana para karyawan memandang pekerjaan mereka (Handoko, 2012). Teori tersebut sesuai dengan penelitian Widya Paramita, Wendi Hadi Prayuda dan Agung Wahyu Handaru (2013) yang memiliki hasil yang sama dengan penelitian Mai Ngac Khuong (2013) dan Astri Aslam, Asri Laksmi dan Gunawan Pamudji W. (2013) yang menyatakan bahwa lingkungan kerja berpengaruh positif dan signifikan terhadap kepuasan kerja karyawan. Berdasarkan uraian di atas, dapat ditarik hipotesis 6 sebagai berikut:

H6: Ada pengaruh positif lingkungan kerja terhadap kepuasan kerja

\section{Hubungan Motivasi dan Kepuasan Kerja}

Motivasi (motivation) adalah proses-proses psikologi yang menjelaskan intensitas, arahan, dan ketekunan seorang individu untuk mencapai tujuannya atau goal-directed behavior (Kreitner dan Angelo, 2005). Intensitas berhubungan dengan seberapa giat seseorang berusaha. Intensitas yang tinggi sepertinya tidak akan menghasilkan prestasi kerja yang memuaskan kecuali upaya tersebut dikatakan dengan arah yang menguntungkan organisasi (Robbins, 2010). Tujuan motivasi menurut Satrianegara dan Sitti (2009) adalah untuk mengubah perilaku bawahan sesuai dengan keinginan pimpinan, meningkatkan kegairahan kerja, meningkatkan disiplin, meningkatkan kesejahteraan, meningkatkan moral dan loyalitas, dan meningkatkan rasa tanggung jawab karyawan pada tugas-tugasnya, serta meningkatkan produktivitas dan efisiensi. Vecchio (dalam Wibowo, 2013) menyatakan kepuasan kerja sebagai pemikiran, perasaan dan kecenderungan tindakan seseorang yang merupakan sikap seseorang terhadap pekerjaan. Teori tersebut sesuai dengan penelitian Agus Dwi Nugroho dan Kunartinah (2012) dan Khalizani Khalid, Hanisah Mat Salim and SiewPhaik Loke (2011) yang menyatakan bahwa motivasi kerja berpengaruh positif terhadap kepuasan kerja. Berdasarkan uraian di atas, dapat ditarik hipotesis 7 sebagai berikut:

H7: Ada pengaruh positif motivasi kerja terhadap kepuasan kerja

Model penelitian dalam studi ini dapat disusun seperti ditunjukkan pada Gambar 1 berikut:

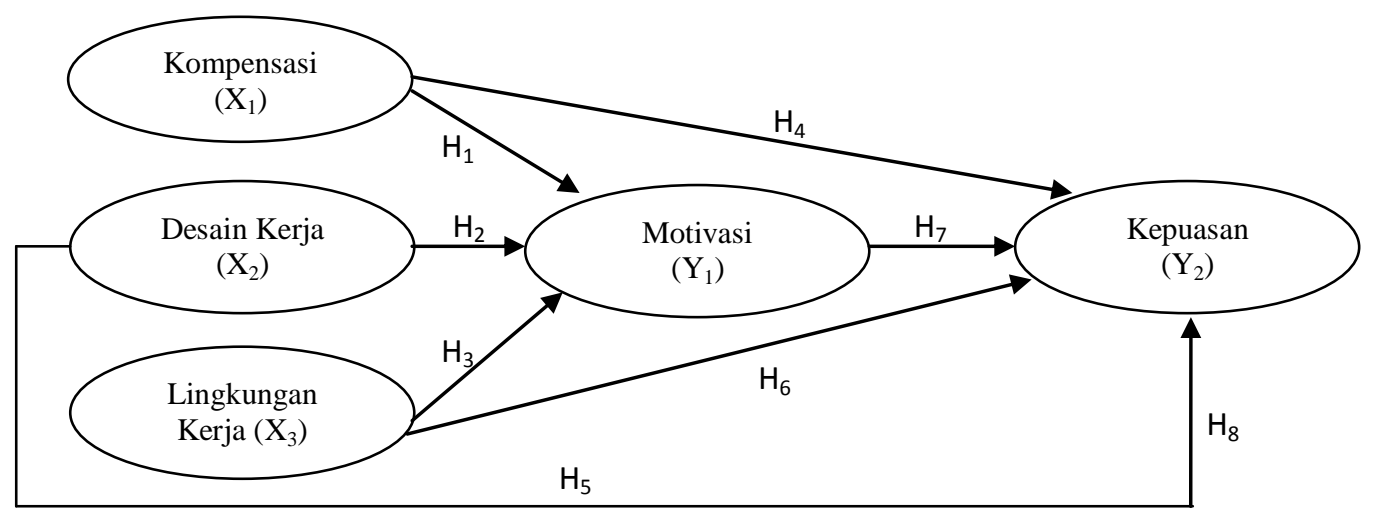

Gambar 1. Model Penelitian 


\section{METODE PENELITIAN}

Populasi dalam penelitian ini adalah karyawan Matahari Departement Store cabang Paragon Semarang yang berjumlah 115 orang, namun yang menjadi responden hanya sebanyak 86 responden. Kepuasan kerja adalah pemikiran, perasaan dan kecenderungan tindakan seseorang yang merupakan sikap seseorang terhadap pekerjaan (Vecchio dalam Wibowo, 2013). Variabel kepuasan kerja secara operasional diukur dengan menggunakan 5 (lima) indikator (Kreitner dan Angelo, 2005). Motivasi kerja adalah proses yang menyebabkan intensitas (intensity), arah (direction) dan usaha terus-menerus (persistence) individu menuju pencapaian tujuan (Robbins, 2010). Variabel motivasi kerja secara operasional diukur dengan menggunakan 5 (lima) indikator (Daft, 2003). Kompensasi adalah apa yang seorang pekerja terima sebagai balasan dari pekerjaan yang diberikannya (William B. Werther dan Keith Davis dalam Hasibuan, 2005). Variabel kompensasi secara operasional diukur dengan menggunakan 7 (tujuh) indikator (Hasibuan, 2005). Desain kerja adalah proses penentuan tugas yang akan dilaksanakan, metode yang digunakan untuk melaksanakan tugas, dan bagaimana pekerjaan berhubungan dengan pekerjaan lainnya di dalam organisasi (Simamora, 2004). Variabel desain kerja secara operasional diukur dengan menggunakan 5 (lima) indikator (Mathis dan John, 2001). Lingkungan kerja adalah segala sesuatu yang ada disekitar para pekerja dan yang dapat mempengaruhi dirinya dalam menjalankan tugas-tugas yang dibebankan kepadanya (Semito, A.N., 2006). Variabel lingkungan kerja secara operasional diukur dengan menggunakan 10 (sepuluh) indikator (Sedarmayanti, 2009). Pengujian instumen untuk validitas menggunakan faktor analisis, sedangkan reliabilitas menggunakan alpha cronbach. Analisis data menggunakan regresi berganda, sedangkan uji efek mediasi menggunakan sobel test.

\section{HASIL DAN PEMBAHASAN}

Mayoritas responden yang terlibat dalam penelitian ini yaitu berdasarkan jenis kelamin sebanyak 63 responden $(73,3 \%)$ adalah perempuan, dengan usia antara 21-30 tahun sebanyak 66 responden $(76,7 \%)$, sedangkan pendidikan terakhir mayoritas responden yaitu sebanyak 67 responden $(77,9 \%)$ berpendidikan SMA, dan masa kerja mereka mayoritas antara 1-5 tahun sebanyak 56 reponden $(65,1 \%)$, serta lama penempatan di Matahari cabang Paragon sebagai pramuniaga sebanyak 35 responden $(40,7 \%)$, serta mayoritas masih berstatus tenaga kerja kontrak yaitu sebanyak 48 responden $(55,8 \%)$. Adapun deskripsi variabel dalam penelitian ini seperti disajikan pada tabel 1 berikut:

Tabel 1. Means, Standar Deviasi, Reliabilitas, dan Korelasi

\begin{tabular}{llccccccc}
\hline No & Variabel & $\begin{array}{c}\text { Mean } \\
\text { s }\end{array}$ & $\begin{array}{c}\text { Standar } \\
\text { Deviasi }\end{array}$ & $\begin{array}{c}\text { Kompen } \\
\text { sasi }\end{array}$ & $\begin{array}{c}\text { Desain } \\
\text { Kerja }\end{array}$ & $\begin{array}{c}\text { Lingkungan } \\
\text { Kerja }\end{array}$ & Motivasi & $\begin{array}{c}\text { Kepuasan } \\
\text { Kerja }\end{array}$ \\
\hline 1 & $\begin{array}{l}\text { Kompesa } \\
\text { si }\end{array}$ & 3,19 & 0,49 & 0,69 & & & & \\
2 & $\begin{array}{l}\text { Desain } \\
\text { Kerja }\end{array}$ & 3,12 & 0,63 & 0,33 & 0,60 & & & \\
& $\begin{array}{l}\text { Lerjakng } \\
3\end{array}$ & 3,09 & 0,57 & 0,21 & 0,45 & 0,80 & & \\
& $\begin{array}{l}\text { Lingkun } \\
\text { an Kerja }\end{array}$ & & & & & & & \\
4 & Motivasi & 3,25 & 0,67 & 0,52 & 0,59 & 0,57 & 0,62 & \\
5 & $\begin{array}{l}\text { Kepuasan } \\
\text { Kerja }\end{array}$ & 3,28 & 1,46 & 0,33 & 0,28 & 0,23 & 0,35 & 0,69 \\
\hline
\end{tabular}

Berdasarkan hasil uji instrumen menunjukkan bahwa nilai KMO (Keiser Meyer Olkin of Sampling Adequacy) untuk semua variabel menghasilkan nilai lebih dari 0,5 sehingga 
sampel dikatakan memenuhi. Hasil uji validitas menunjukkan bahwa ada dua variabel yang memiliki indikator yang tidak valid, yaitu kompensasi untuk indikator pertama, dan lingkungan kerja pada indikator ke-9, sedangkan untuk nilai loading untuk indikator-indikator lain memiliki nilai loading lebih besar dari 0,4 sehingga dapat dikatakan bahwa indikator tersebut dikatakan valid. Berdasarkan uji reliabilitas juga menunjukkan bahwa semua variabel yang dipakai adalah reliabel.

Proses analisis menggunakan regresi linier berganda untuk menguji pengaruh kompensasi, desain kerja, dan lingkungan kerja terhadap motivasi kerja dan kepuasan kerja dengan hasil seperti pada tabel 2 berikut:

Tabel 2. Hasil Regresi

\begin{tabular}{cllcc}
\hline Model & \multicolumn{1}{c}{ Dependen } & \multicolumn{1}{c}{ Independen } & Beta & Sign \\
\hline 1 & Motivasi & Kompensasi & 0.259 & 0.003 \\
& & Desain Kerja & 0.307 & 0.001 \\
& & Lingkungan Kerja & 0.350 & 0.000 \\
& & & & \\
& Adj R ${ }^{2}: 0.546$ & & & 0.000 \\
\hline $2 \quad: 35.063$ & Kepuasan Kerja & Kompensasi & 0.257 & 0.019 \\
& & Desain Kerja & 0.182 & 0.120 \\
& & Lingkungan Kerja & 0.037 & 0.751 \\
& & Motivasi & 0.314 & 0.003 \\
& Adj R ${ }^{2}: 0.312$ & & & \\
& F $: 15.954$ & & & 0.000 \\
\hline
\end{tabular}

\section{Pengaruh Kompensasi Terhadap Motivasi Kerja}

Hasil perhitungan yang telah dilakukan, diperoleh nilai t untuk kompensasi terhadap motivasi kerja dengan hasil signifikasi sebesar 0,003 $(<0,05)$. Hal ini menunjukkan terdapat pengaruh positif yang signifikan antara kompensasi terhadap motivasi kerja. Penjelasan tersebut dapat diartikan bahwa hipotesis yang menyatakan kompensasi berpengaruh positif terhadap motivasi diterima. Hal ini berarti bahwa ketika kompensasi meningkat, maka motivasi kerja juga akan meningkat.

Hasil penelitian menunjukkan bahwa kompensasi memiliki pengaruh langsung yang positif terhadap motivasi kerja. Penelitian ini menyimpulkan bahwa semakin baik kompensasi yang diberikan pada karyawan Matahari Departement Store cabang Paragon Semarang maka motivasi kerja karyawan juga akan semakin baik. Nilai beta yang dihasilkan kompensasi terhadap motivasi kerja adalah sebesar 0,259. Studi ini mendukung teori bahwa susunan kompensasi yang ditetapkan dengan baik akan memberikan motivasi kerja bagi karyawan. Jika balas jasa yang diberikan cukup besar, manajer akan mudah memotivasi bawahannya (Hasibuan, 2005). Kompensasi, penempatan karyawan, pelatihan dan pengembangan, manajemen kinerja, serta praktik-praktik manajemen sumber daya manusia lainnya merupakan investasi-investasi yang langsung memengaruhi motivasi para karyawan dan kemampuan untuk menyediakan produk dan jasa yang dihargai oleh para pelanggan (Noe, dkk, 2011). 


\section{Pengaruh Desain Kerja Terhadap Motivasi Kerja}

Hasil perhitungan yang telah dilakukan, diperoleh nilai t untuk desain kerja terhadap motivasi kerja dengan hasil signifikasi sebesar 0,001 $(<0,05)$. Hal ini menunjukkan terdapat pengaruh positif antara desain kerja terhadap motivasi kerja. Penjelasan tersebut dapat diartikan bahwa hipotesis yang menyatakan desain kerja berpengaruh positif terhadap motivasi diterima. Hal ini berarti bahwa ketika desain kerja bagus, maka motivasi kerja juga akan meningkat.

Hasil penelitian menunjukkan bahwa desain kerja memiliki pengaruh langsung yang positif terhadap motivasi kerja. Penelitian ini menyimpulkan bahwa semakin baik desain kerja yang diterapkan pada karyawan Matahari Departement Store cabang Paragon Semarang maka motivasi kerja karyawan juga akan semakin baik. Nilai beta yang dihasilkan desain kerja terhadap motivasi kerja adalah sebesar 0,307. Desain pekerjaan (job design) merupakan proses penentuan tugas yang akan dilaksanakan, metode yang digunakan untuk melaksanakan tugas, dan bagaimana pekerjaan berhubungan dengan pekerjaan lainnya di dalam organisasi (Henry, 2004). Satu pekerjaan yang membosankan dan monoton menghalangi motivasi untuk berprestasi baik, sedangkan suatu pekerjaan yang menantang akan meningkatkan motivasi (Robert Kreitner dan Angelo, 2005).

\section{Pengaruh Lingkungan Kerja Terhadap Motivasi Kerja}

Hasil perhitungan yang telah dilakukan, diperoleh nilai t hitung untuk lingkungan kerja dengan hasil signifikansi sebesar $0,000<0,05$. Hal ini menunjukkan terdapat pengaruh positif antara lingkungan kerja terhadap motivasi kerja. Penjelasan tersebut dapat diartikan bahwa hipotesis yang menyatakan lingkungan kerja berpengaruh positif terhadap motivasi kerja dapat diterima. Kondisi ini dapat diartikan bahwa ketika lingkungan kerja bagus, maka motivasi kerja para. karyawan akan meningkat, demikian juga sebaliknya.

Penelitian menyimpulkan bahwa semakin baik lingkungan kerja yang diberikan pada karyawan Matahari Departement Store cabang Paragon Semarang maka motivasi kerja karyawan juga akan semakin baik. Kontribusi langsung yang diberikan lingkungan kerja terhadap motivasi kerja adalah sebesar 0,350, ini menjelaskan bahwa perubahan motivasi kerja pada karyawan Matahari Departement Store cabang Paragon Semarang dipengaruhi oleh lingkungan kerja yang baik dengan besarnya pengaruh yang diberikan adalah $35 \%$. Menurut Semito (dalam Widya, Wendi dan Agung, 2013) bahwa lingkungan kerja adalah segala sesuatu yang ada disekitar para pekerja dan yang dapat mempengaruhi dirinya dalam menjalankan tugas-tugas yang dibebankan kepadanya. Motivasi menurut M. Fais dan Sitti (2009) diartikan sebagai pernyataan perasaan atau pikiran yang membantu terciptanya kerja yang optimal. Lingkungan yang sehat memungkinkan manusia bekerja secara sehat dan bergairah (Danim, 2008).

\section{Pengaruh Kompensasi Terhadap Kepuasan Kerja}

Hasil analisis statistik diperoleh nilai t hitung untuk kompensasi terhadap kepuasan kerja dengan hasil signifikasi sebesar $0,019<0,05$. Hal ini menunjukkan terdapat pengaruh positif antara kompensasi terhadap kepuasan kerja. Penjelasan tersebut dapat diartikan bahwa hipotesis yang menyatakan bahwa kompensasi berpengaruh positif terhadap kepuasan kerja dapat diterima. Kondisi ini mmemiliki arti bahwa apabila kompensasi para pegawai naik, maka kepuasan kerja mereka juga akan meningkat, demikian juga sebaliknya.

Penelitian ini menyimpulkan bahwa semakin baik kompensasi yang diberikan pada karyawan Matahari Departement Store cabang Paragon Semarang maka kepuasan kerja karyawan juga akan semakin baik. Kontribusi langsung yang diberikan kompensasi terhadap kepuasan kerja adalah sebesar 0,257, ini menjelaskan bahwa perubahan kepuasan kerja pada karyawan Matahari Departement Store cabang Paragon Semarang dipengaruhi oleh 
kompensasi yang baik dengan besarnya pengaruh yang diberikan adalah 25,7\%. William B. Werther dan Keith Davis (Hasibuan, 2005) menyatakan bahwa kompensasi adalah apa yang seorang pekerja terima sebagai balasan dari pekerjaan yang diberikannya. Kepuasan kerja adalah sikap umum terhadap pekerjaan seseorang, yang menunjukkan perbedaan antara jumlah penghargaan yang diterima pekerja dan jumlah yang mereka yakini seharusnya mereka terima menurut Robbins (Wibowo, 2013). Studi ini juga mendukung penelitian yang dilakukan oleh Agus Dwi Nugroho dan Kunartinah (2012) .Balas jasa yang diterima para karyawan akan dapat memenuhi kebutuhan-kebutuhan fisik, status sosial dan egoistiknya sehingga memperoleh kepuasan kerja dari jabatannya (Hasibuan, 2005). Membangun suatu sistem kompensasi yang efektif adalah bagian penting dari manajemen sumber daya manusia karena sistem ini dapat membantu menarik dan mempertahankan pekerjaan-pekerjaan berbakat (Daft, 2010).

\section{Pengaruh Desain Kerja Terhadap Kepuasan Kerja}

Hasil analisis statistik menunjukkan bahwa nilai t hitung untuk desain kerja terhadap kepuasan kerja diperoleh nilai signifikasi sebesar 0,120 >0,05. Hal ini menunjukkan bahwa hipotesis yang menyatakan bahwa terdapat pengaruh positif antara desain kerja terhadap kepuasan kerja tidak dapat diterima. Temuan ini berbeda dengan studi yang dilakukan oleh Hafanti, O., (2015) dan I Nyoman Parta Jaya (2015) yang menyatakan bahwa desain kerja berpengaruh secara positif terhadap kepuasan kerja.

Desain kerja menurut Wibowo (2013) diartikan mengubah konten dan/atau proses pekerjaan spesifik untuk meningkatkan kepuasan kerja dan kinerja. Reaksi karyawan yang simpatik terhadap desain pekerjaan bermakna penuntasan yang lebih besar, kepuasan kerja yang lebih tinggi, ketidakhadiran yang lebih sedikit, keluhan yang lebih jarang dan putaran karyawan yang lebih rendah (Simamora, 2004). Greenberg dan Baron (Wibowo, 2013) mendeskripsikan kepuasan kerja sebagai sikap positif atau negatif yang dilakukan individual terhadap pekerjaan mereka.

\section{Pengaruh Lingkungan Kerja Terhadap Kepuasan Kerja}

Hasil analisis statistik dalam studi ini diperoleh nilai t hitung untuk lingkungan kerja terhadap kepuasan kerja dengan nilai signifikasi sebesar 0,751 >0,05. Hal ini menunjukkan tidak terdapat pengaruh lingkungan kerja terhadap kepuasan kerja. Hasil penelitian menunjukkan bahwa lingkungan kerja tidak memiliki pengaruh terhadap kepuasan kerja. Hasil tersebut sesuai dengan hasil penelitian Anak Agung, I Gde dan I Wayan (2012) yang menyatakan bahwa lingkungan kerja tidak berpengaruh terhadap kepuasan kerja.

Temuan studi ini tidak sesuai dengan yang dikemukakan oleh Denim (2008) yang menunjukkan bahwa lingkungan yang sehat bercirikan iklim yang bebas dan terarah, tidak ada rasa curiga, rasa puas didalam diri, toleransi antar teman dan kesadaran tinggi akan tugastugas akan berdampak pada kepuasan kerja. Rivai dalam Widya, Wendi dan Agung (2013) mendefinisikan lingkungan kerja adalah keseluruhan sarana dan prasarana yang ada disekitar karyawan yang sedang melakukan pekerjaan itu sendiri. Dengan lingkungan kerja yang baik, maka secara otomatis dapat memberikan kepuasan tersendiri bagi karyawan (Widya, Wendi dan Agung, 2013).

\section{Pengaruh Motivasi Kerja Terhadap Kepuasan Kerja}

Hasil analisis statistik diperoleh nilai t hitung untuk motivasi kerja terhadap kepuasan kerja adalah 3,033 dengan tingkat signifikasi sebesar 0,003 $<0,05$. Hal ini menunjukkan terdapat hipotesis yang menyatakan bahwa ada pengaruh positif antara motivasi kerja terhadap kepuasan kerja dapat diterima. Hal ini dapat diartikan bahwa jika motivasi kerja 
lebih ditingkatkan maka kepuasan kerja juga akan meningkat. Hasil penelitian menunjukkan bahwa motivasi kerja memiliki pengaruh yang signifikan dan positif terhadap kepuasan kerja. Penelitian ini menyimpulkan bahwa semakin baik motivasi kerja yang ada pada karyawan Matahari Departement Store cabang Paragon Semarang maka kepuasan kerja karyawan juga akan semakin baik. Kontribusi langsung yang diberikan motivasi kerja terhadap kepuasan kerja adalah sebesar 0,314, ini menjelaskan bahwa peningkatan kepuasan kerja pada karyawan Matahari Departement Store cabang Paragon Semarang dipengaruhi oleh motivasi kerja yang baik dengan besarnya pengaruh yang diberikan.

Hal ini sesuai dengan Kreitner \& Angelo (2005) yang mengatakan bahwa Motivasi (motivation) adalah proses-proses psikologi yang menjelaskan intensitas, arahan dan ketekunan seorang individu untuk mencapai tujuannya atau goal-directed behavior (Robert Kreitner dan Angelo, 2005). Intensitas berhubungan dengan seberapa giat seseorang berusaha. Intensitas yang tinggi sepertinya tidak akan menghasilkan prestasi kerja yang memuaskan kecuali upaya tersebut dikatakan dengan arah yang menguntungkan organisasi. Vecchio (Wibowo, 2013) menyatakan kepuasan kerja sebagai pemikiran, perasaan dan kecenderungan tindakan seseorang yang merupakan sikap seseorang terhadap pekerjaan. Motivasi kerja individual berhubungan dengan kepuasan kerja. Kepuasan kerja adalah respons bersifat memengaruhi terhadap berbagai segi pekerjaan seseorang (Wibowo, 2013). Studi ini mendukung penelitian sebelumnya yang dilakukan oleh Agus Dwi Nugroho dan Kunartinah (2012) dan Khalizani Khalid, Hanisah Mat Salim and Siew-Phaik Loke (2011).

\section{Kompensasi Berpengaruh Terhadap Kepuasan Kerja Dengan Mediasi Motivasi Kerja}

Hasil yang didapatkan dari analisis pengaruh langsung antara kompensasi terhadap kepuasan kerja memberikan pengaruh yang positif dengan nilai beta sebesar 0,257, yang menyatakan bahwa kompensasi dalam Matahari Departement Store cabang Paragon Semarang memberikan pengaruh yang cukup tinggi terhadap kepuasan kerja karyawan. Adapun pengaruh tak langsung yang melibatkan motivasi kerja sebagai variabel intervening, diperoleh nilai beta sebesar 0,081. Hal ini berarti bahwa dengan pengaruh langsung yang lebih besar dari pengaruh tidak langsungnya, maka dapat dikatakan bahwa untuk meningkatkan kepuasan kerja karyawan, akan lebih cepat dengan memperhatikan kompensasi yang baik bagi mereka.

Kompensasi adalah segala sesuatu yang diterima para karyawan sebagai balas jasa untuk kerja mereka (Hasibuan, 2005). Bila para karyawan memandang kompensasi mereka tidak memadahi, prestasi kerja, dan kepuasan kerja mereka bisa turun secara dramatis (Simamora, 2004). Tujuan pemberian kompensasi (balas jasa) antara lain adalah sebagai ikatan kerja sama, kepuasan kerja, pengadaan efektif, stabilitas karyawan, disiplin serta pengaruh serikat buruh dan pemerintah (Wibowo, 2013). Kompensasi tidak langsung (kesejahteraan) berbentuk uang dan barang (natura) supaya dapat merangsang gairah dan kepuasan kerja karyawan serta mendorong terwujudnya sasaran perusahaan (Hasibuan, 2005).

\section{Desain Kerja Berpengaruh Terhadap Kepuasan Kerja Dengan Mediasi Motivasi Kerja}

Hasil yang didapatkan dari hipotesis terhadap pengaruh langsung antara desain kerja terhadap kepuasan kerja tidak didukung. Hal ini memberikan arti bahwa tidak ada pengaruh langsung desain kerja terhadap kepuasan kerja karyawan. Sehingga memiliki makna bahwa keberadaan motivasi kerja dalam penelitian ini sebagai mediasi dalam pengaruh antara desain kerja terhadap kepuasan kerja.

Desain pekerjaan menentukan bagaimana pekerjaan dilakukan, oleh karena itu sangat mempengaruhi sikap karyawan terhadap sebuah pekerjaan, seberapa banyak tugas yang harus dirampungkan oleh karyawan (Simamora, 2004). Desain pekerjaan (job design) adalah aplikasi dari teori motivasi pada struktur kerja untuk memperbaiki produktivitas dan kepuasan 
(Wibowo, 2013). Job design adalah mengubah konten dan/atau proses pekerjaan spesifik untuk meningkatkan kepuasan kerja dan kinerja. Motivasi kerja individual berhubungan dengan kepuasan kerja. Kepuasan kerja adalah respons bersifat memengaruhi terhadap berbagai segi pekerjaan seseorang.

\section{Lingkungan Kerja Berpengaruh Terhadap Kepuasan Kerja Dengan Mediasi Motivasi Kerja}

Hasil yang didapatkan dari hipotesis terhadap pengaruh langsung antara lingkungan kerja terhadap kepuasan kerja tidak didukung. Hal ini memberikan arti bahwa tidak ada pengaruh langsung lingkungan kerja terhadap kepuasan kerja karyawan. Sehingga memiliki makna bahwa keberadaan motivasi kerja dalam penelitian ini sebagai mediasi dalam pengaruh antara lingkungan kerja terhadap kepuasan kerja.

Kepuasan kerja adalah keadaan emosional yang menyenangkan atau tidak menyenangkan dengan mana para karyawan memandang pekerjaan mereka (Handoko, 2012). Robert A. Baron (Wibowo, 2013) berpendapat bahwa motivasi merupakan serangkaian proses yang membangkitkan (arouse), mengarahkan (direct) dan menjaga (maintain) perilaku manusia menuju pada pencapaian tujuan. Lingkungan yang sehat memungkinkan manusia bekerja secara sehat dan bergairah. Lingkungan yang dimaksudkan disini terutama adalah lingkungan sosial yang melahirkan suasana psikologis yang menyenangkan. Lingkungan yang sehat bercirikan iklim yang bebas dan terarah, tidak ada rasa curiga, rasa puas didalam diri, toleransi antar teman dan kesadaran tinggi akan tugas-tugas (Danim, 2008). Mengelola faktorfaktor lingkungan internal dan eksternal memungkinkan para karyawan untuk membuat kontribusi terbesar terhadap produktivitas dan daya saing perusahaan (Noe, dkk, 2011).

\section{SIMPULAN}

Berdasarkan hasil studi menunjukkan bahwa kepuasan kerja para pegawai dapat dicapai dengan tiga cara sebagai berikut:

Kompensasi merupakan pengaruh terkuat yang akan dapat meningkatkan kepuasan kerja mereka secara langsung. Hal ini tercermin dalam perhatian perusahaan untuk kompensasi langsung dalam bentuk pemberian asuransi dan insentif, sedangkan untuk kompensasi tidak langsung adalah fleksibel terhadap cuti karena sakit. Hal ini akan berdampak langsung terhadap kepuasan dari pemberian imbalan/balas jasa yang mereka terima, puas terhadap atasan/supervisornya, dan puas terhadap pekerjaan itu sendiri.

Faktor kedua yang akan meningkatkan kepuasan kerja adalah lingkungan kerja yang kondusif, karena hal ini akan memotivasi kerja mereka, dan pada akhirnya akan meningkatkan kepuasan kerjanya. Faktor lingkungan yang paling membuat para karyawan termotivasi diantaranya adalah lingkungan fisik yang berupa kebersihan lingkungan kerja, tidak bising, sirkulasi udara yang bagus, dan suhu ruang kerja yang sejuk. Sedangkan lingkungan non fisik yang membuat mereka termotivasi adalah adanya hubungan baik yang terjalin dengan para pelanggan. Semua faktor ini akan membuat mereka memiliki aktualisasi diri, lebih aman dalam bekerja, dan memenuhi kebutuhan fisiknya.

Cara ketiga yang akan mampu meningkatkan kepuasan kerja para karyawan adalah dari desain kerja yang baik, dimana hal ini akan memotivasi kerja mereka dan pada akhirnya akan berdampak pada kepuasan kerjanya. Desain kerja dicerminkan dari adanya pemberian otonomi atau kewenangan dalam pekerjaan, pemberian umpan balik atas kerja mereka, sehingga para pegawai akan selalu terpantau tugasnya, dan adanya variasi tugas/ketrampilan dalam menjalankan tugas dan kewajibannya. Faktor-faktor ini akan mampu memotivasi mereka, sehingga berdampak pada kepuasan kerjanya. 
Atas dasar kesimpulan yang telah dikemukakan, dapat diberikan beberapa saran dan diharapkan dapat berguna bagi kemajuan perusahaan. Adapun saran tersebut adalah:

Berdasarkan hasil penelitian mengenai kompensasi yang menjadi faktor terkuat terhadap kepuasan kerja. Dan pengaruh langsung kompensasi terhadap kepuasan kerja lebih tinggi dibandingkan pengaruh tidak langsung melalui motivasi kerja dan bernilai positif. Sehingga perusahaan perlu lebih memperhatikan kompensasi untuk dapat meningkatkan kepuasan kerja. Dalam meningkatkan persepsi yang baik terhadap kompensasi hal yang dapat dilakukan perusahaan yaitu perusahaan perlu lebih memperhatikan kelayakan gaji yang disesuaikan dengan beban kerja dan hasil kerja, pemberian bonus dan insentif tidak terlambat dan sesuai dengan prestasi kerja yang telah diperoleh, pemberian asuransi lebih diperjelas batasan-batasan pemakaiannya, lebih mempermudah karyawan mengambil cuti ketika sakit dan darmawisata perusahaan lebih bisa di gratiskan atau tanpa biaya tambahan dari karyawan.

Berdasarkan hasil penelitian mengenai desain kerja terlihat bahwa faktor desain kerja memiliki pengaruh yang signifikan dan positif terhadap motivasi kerja. Motivasi kerja memiliki pengaruh yang signifikan dan positif terhadap kepuasan kerja. Dalam pengaruh persepsi terhadap desain kerja, indikator yang memiliki pengaruh yang cukup tinggi yaitu identitas tugas dan umpan balik. Perusahaan hendaknya lebih memperjelas identitas tugas yang harus dilakukan karyawan, memperjelas apa saja yang perlu dilakukan karyawan dan apa saja yang tidak boleh dilakukan oleh karyawan, melakukan pertemuan rutin untuk membahas, bertukar pendapat mengenai pekerjaan, dan untuk memberitahukan kepada setiap karyawan hasil kerja setiap minggunya. Reaksi karyawan yang simpatik terhadap desain pekerjaan bermakna penuntasan yang lebih besar, kepuasan kerja yang lebih tinggi, ketidakhadiran yang lebih sedikit, keluhan yang lebih jarang dan putaran karyawan yang lebih rendah.

Berdasarkan hasil penelitian mengenai lingkungan kerja terlihat bahwa faktor lingkungan kerja memiliki pengaruh yang signifikan dan positif terhadap motivasi kerja. Motivasi kerja memiliki pengaruh yang signifikan dan positif terhadap kepuasan kerja. Melihat kebutuhan penerimaan/sosial memiliki skor paling tinggi dalam variabel motivasi, dan kepuasan terhadap rekan sekerja memiliki skor tertinggi dari kepuasan kerja maka lingkungan kerja yang perlu lebih diperhatikan yaitu hubungan antara karyawan dengan rekan sekerja. Dalam mempererat hubungan antara karyawan dengan rekan sekerjanya, perusahaan dapat melakukannya dengan cara lebih sering melakukan outbond atau darmawisata, makan bersama, ada lomba di setiap cabang, pertemuan setiap pagi sebelum mulai bekerja untuk saling bertukar pendapat atau saling menyapa dan memberi semangat.

\section{DAFTAR PUSTAKA}

Abdurahman., Maman, dan Sambas A.M. 2007. Analisis Korelasi, Regresi, dan Jalur dalam Penelitian (Dilengkapi Aplikasi Program SPSS). Bandung: Pustaka Setia.

Daft., Richard L.2003. Manajemen. Jakarta: Erlangga. . 2010. Era Baru Manajemen. Jakarta: Salemba Empat.

Danim., Sudarwan. 2008. Kinerja Staf dan Organisasi. Bandung: CV Pustaka Setia.

Dhermawan, A.A.N.B., I Gde A.S. dan I Wayan M.U. 2012. Pengaruh Motivasi, Lingkungan Kerja, Kompetensi dan Kompensasi terhadap Kepuasan Kerja dan Kinerja Pegawai di Lingkungan Kantor Dinas Pekerjaan Umum Provinsi Bali. Jurnal Manjemen, Strategi Bisnis dan Kewirausahaan. 6 (2).

Handoko, T.H. 2012. Manajemen Personalia dan Sumberdaya Manusia. Yogyakarta: BPFE. Hasibuan, Malayu S.P. 2005. Manajemen Sumber Daya Manusia. PT Bumi Aksara, Jakarta. 
Khalizani Khalid, Hanisah Mat Salim and Siew-Phaik Loke. 2011. The Impact of Rewards and Motivation on Job Satisfaction in Water Utility Industry. International Conference on Financial Management and Economics (IPEDR). 11.

Kreitner, R., dan Angelo K. 2005. Perilaku Organisasi. Jakarta: Salemba Empat.

Mathis, R.L., dan John H.J. 2001. Manajemen Sumber Daya Manusia. Jakarta: Salemba Empat.

Noe, R.A., dkk. 2011. Manajemen Sumber Daya Manusia: Mencapai Keunggulan Bersaing.. Jakarta: Salemba Empat.

Nugroho, A.D. dan Kunartinah. 2012. Analisis Pengaruh Kompensasi dan Pengembangan Karier terhadap Kepuasan Kerja dengan Mediasi Motivasi Kerja. Jurnal Bisnis dan Ekonomi (JBE), 19 (1412-3126).

Nyoman P.J., I. 2015. Pengaruh Upah dan Karakteristik Pekerjaan terhadap Kepuasan Kerja Karyawan Bagian Pemasaran Instalasi Listrik di CV. Putra Tunggal Jaya Tahun 2013. Jurnal Jurusan Pendidikan Ekonomi (JJPE). 5 (1).

Paramita, W., Wendi H.P. dan Agung W.H. 2013. Pengaruh Lingkungan Kerja dan Budaya Organisasi terhadap Kepuasan Kerja Karyawan pada Bank BTN (Persero) Cabang Bekasi. Jurnal Riset Manajemen Sains Indonesia (JRMSI). 4 (2)..

Satrianegara, M. F. dan Sitti S. 2009. Buku Ajar Organisasi dan Manajemen Pelayanan Kesehatan serta Kebidanan. Jakarta: Salemba Medika.

Sedarmayanti. 2009. Sumber Daya Manusia dan Produktivitas Kerja. Bandung: CV. Mandar Maju.

Simamora, H. 2004. Manajemen Sumber Daya Manusia. Yogyakarta: STIE YKPN

Totterdill, P. 2017. Job Design. UKWON (The UK Work Organisation Network).

Wibowo. 2013. Manajemen Kinerja, Jakarta: PT Raja Grafindo Persada. 